\title{
Almond Oil
}

National Cancer Institute

\section{Source}

National Cancer Institute. Almond Oil. NCI Thesaurus. Code C107259.

The oil extracted from the seed fruits of Prunus amyg dalus. Almond oil is typically used as a skin emollient and for massage. 